\title{
Influence of Intensive Agriculture on Dry Deposition of Aerosol Nutrients
}

\author{
Andrew G. Allen, ${ }^{*, a}$ Arnaldo A. Cardoso, ${ }^{a}$ Antony G. Wiatr, ${ }^{b}$ Cristine M. D. Machado, ${ }^{a}$ \\ Willian C. Paterlini ${ }^{a}$ and Jacob Baker ${ }^{b}$ \\ ${ }^{a}$ Instituto de Química, Universidade Estadual Paulista, CP 355, 14801-970 Araraquara-SP, Brazil \\ ${ }^{b}$ University of Birmingham, School of Geography, Earth and Environmental Sciences, Edgbaston, \\ Birmingham, B15 2TT, UK
}

\begin{abstract}
É apresentado um modelo para quantificação de fontes e deposição de espécies nutrientes que contribuem com a formação e concentração do aerossol atmosférico. Para este procedimento foram utilizadas ferramentas estatísticas como: a análise de componentes principais (PCA) e análise de regressão linear múltipla (MLRA) associadas a modelos de deposição de partículas segregadas por tamanho. Em região rural do sudeste do Brasil, a queima de biomassa, produtos de reações secundárias, e re-suspensão de poeira do solo possibilitaram explicar $43 \%, 31 \%$ e $21 \%$ da massa do $\mathrm{MP}_{25}$, respectivamente. A re-suspensão de poeira e a queima de biomassa contribuíram com $22 \%$ e $19 \%$, respectivamente, da massa do $\mathrm{MP}_{10}$. A re-suspensão possibilitou explicar cerca da metade da massa das partículas grossas. Cerca de $40 \%$ de $\mathrm{NO}_{3}{ }^{-}-\mathrm{N}, 20 \%$ de fósforo e $55 \%$ de potássio depositados tem origem nas emissões relacionadas com a agricultura. Atualmente a deposição sobre a floresta tropical é aumentada pelos fatores de $12.2(\mathrm{~N}), 6.2(\mathrm{P})$ e $2.6(\mathrm{~K})$ com relação a aqueles que existiam nas condições naturais do passado.
\end{abstract}

A procedure is presented for quantification of sources contributing to atmospheric aerosol chemical nutrient concentrations and dry deposition fluxes. Source apportionment using principal component analysis (PCA) and multiple linear regression analysis (MLRA) was followed by application of a size-segregated particle dry deposition model. In a rural region of southeast Brazil, biomass burning, products of secondary reactions, and soil dust re-suspension explained $43 \%$, $31 \%$ and $21 \%$ of $\mathrm{PM}_{2.5}$ mass, respectively. Re-suspension and biomass burning contributed $22 \%$ and $19 \%$, respectively, to $\mathrm{PM}_{10}$ mass, and re-suspension accounted for approximately half of the mass of coarse particles. At least $40 \%$ of $\mathrm{NO}_{3}{ }^{-} \mathrm{N}, 20 \%$ of phosphorus and $55 \%$ of potassium deposited originated from agriculture-related emissions. Deposition to tropical forest is currently higher than the minimum under natural conditions by factors of $12.2(\mathrm{~N}), 6.2(\mathrm{P})$ and $2.6(\mathrm{~K})$.

Keywords: aerosols, pollution, deposition, nutrients, source apportionment

\section{Introduction}

On a global scale, the atmosphere is the main source of nutrient inputs to terrestrial and aquatic biomes, with dry and wet deposition contributing roughly equal proportions. Although there are numerically few gaseous nutrient species in the atmosphere (the most important are forms of nitrogen, sulphur and chlorine), all of the nutrients required for plant growth can be found within atmospheric aerosols. However, unlike many trace gases, which are quickly removed from the atmosphere by reaction and deposition, aerosols may be transported over greater distances, allowing for wider geographical dispersal of nutrients prior to

*e-mail: andrew@pq.cnpq.br deposition. ${ }^{1}$ The mix and chemical state of nutrients within these particles reflects the mechanisms by which particles are released into, or formed within, the atmosphere. For example, re-suspension of surface dusts and soils generates coarse mineral particles, combustion processes emit fine aerosols composed of a complex mixture of inorganic and organic components, and particulate sulphates are produced by oxidation of sulphur dioxide. Scavenging of gases by pre-existing particles, followed by reactions in the liquid phase or on surfaces, is a source of nitrates, while reduced nitrogen in aerosols is produced by neutralization of acid species by reaction with ammonia or amines.

Greater use of fuels in industrial, transport and domestic applications, and of fertilizers in agriculture, has increased emissions to the atmosphere of all of the 
major and minor nutrients. Of especial significance is the increased contribution of deposition, relative to biological fixation, as a source of bio-available nitrogen. ${ }^{5}$ Although deposition is an integral component of the biogeochemical cycling of elements, increased nutrient inputs in polluted regions can cause ecosystem acidification, eutrophication and reduced species diversity. ${ }^{2}$ Although some studies have suggested that stimulation of more rapid plant growth could increase removal of carbon dioxide from the atmosphere, ${ }^{3}$ potentially partially offsetting increased anthropogenic emissions of the gas, results are not consistent and the opposite effect (increased carbon dioxide emissions from soils, given higher nutrient inputs) has also been reported. ${ }^{4}$

Information is scarce concerning the role of the atmosphere in nutrient transport in the tropics and subtropics, especially concerning aerosols. The present work was conducted in a rural region of southeast Brazil, where economic activity is largely based on sugar cane production and its associated industries, seasonally responsible for widespread atmospheric pollution. Brazil is the global leader in sugar cane cultivation, with a (2005) production of $420 \mathrm{Mt}$, equating to $34 \%$ of the global harvest, from a planted area of $60,000 \mathrm{~km}^{2}{ }^{6}$ São Paulo State's planted area of $29,000 \mathrm{~km}^{2}$ accounts for $c a$. $60 \%$ of Brazil's total production. ${ }^{7}$

\section{Experimental}

\section{Sampling and analysis}

Measurements were made in the municipality of Araraquara, which is centrally located within the main sugar cane growing region of São Paulo State (Figure 1). Equipment was positioned on a well-ventilated rooftop, ca. $25 \mathrm{~m}$ a.g.l., on the Araraquara campus of the State University of São Paulo ( $48^{\circ} 10^{\prime} \mathrm{W}, 21^{\circ}$ 47' S, 664 m a.s.1.).

Between June 2003 and May 2004, particles smaller than $2.5 \mu \mathrm{m}$ diameter $\left(\mathrm{PM}_{2.5}\right)$, as well as those in the size interval between $2.5 \mu \mathrm{m}$ and $c a .15 \mu \mathrm{m}$, were collected on a daily basis ( $24 \mathrm{~h}$ samples) using a stacked filter unit, and particles smaller than $10 \mu \mathrm{m}\left(\mathrm{PM}_{10}\right)$ were collected onto Teflon filters in separate samplers fitted with a small inlet impactor to eliminate particles larger than $10 \mu \mathrm{m}$. Aerosols were also collected onto Teflon filters in twelve size fractions, using a Micro-Orifice Uniform Deposit Impactor (MSP Corporation, USA). The impactor was operated once per month, for a continuous period of 7 days, during the last week of each month.

Particulate mass concentrations were determined by weighing filters before and after sample collection, using a Mettler Toledo AX26 microbalance accurate to $1 \mu \mathrm{g}$, in accordance with international protocol ISO/CD

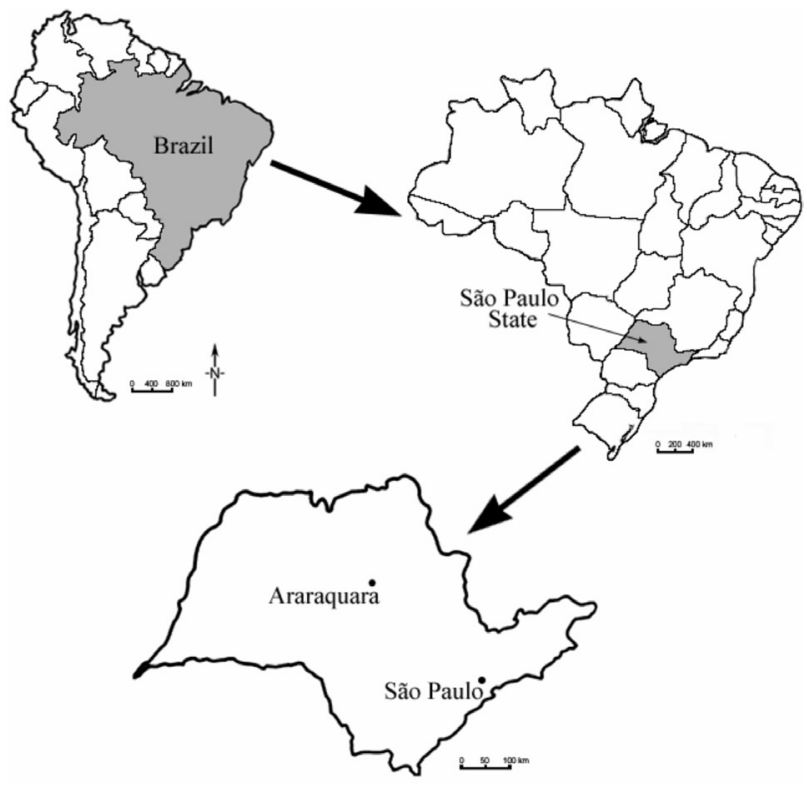

Figure 1. Location of measurement station in southeast Brazil.

15767. The soluble ions $\mathrm{NO}_{3}^{-}, \mathrm{NH}_{4}^{+}, \mathrm{PO}_{4}^{3-}, \mathrm{SO}_{4}^{2-}, \mathrm{Cl}^{-}$, $\mathrm{C}_{2} \mathrm{O}_{4}^{2-}, \mathrm{HCOO}^{-}, \mathrm{CH}_{3} \mathrm{COO}^{-}, \mathrm{K}^{+}, \mathrm{Na}^{+}, \mathrm{Mg}^{2+}$ and $\mathrm{Ca}^{2+}$ were analyzed in aqueous extracts of the impactor substrates and filters, using ion chromatography. ${ }^{8}$ Determination of carbonaceous species was based on a reflectance method, ${ }^{9}$ which assumed elemental carbon (EC) to be the principal light-absorbing particulate species present in ambient air. ${ }^{10}$ A Sunset Laboratory Carbon Analyzer (Model 4L) was used to determine the relative concentrations of elemental and organic carbon (OC). The mass and chemical composition of coarse particles $\left(\mathrm{PM}_{>10}\right)$ were determined as the difference between values for $\mathrm{PM}_{10}$ and the sum of the two size fractions collected by the stacked filter sampler.

\section{Source apportionment procedure}

Identification and quantification of aerosol sources was achieved using principal component analysis (PCA) followed by multiple linear regression analysis (MLRA) of the $24 \mathrm{~h}$ sample data $(n=266)$. All statistical procedures were performed using SPSS for Windows v. 12.0. The data were initially screened, with any concentrations below detection limit being replaced by zero values, and extreme outliers removed (fewer than 5\% replacements in all cases). The principal component extraction method employed orthogonal (Varimax) rotational transformation.

\section{Dry deposition flux estimates}

Dry deposition fluxes were determined by integrating the measured atmospheric concentrations, corresponding 
to the material collected on each impactor stage, with a mean modeled dry deposition velocity $\left(\mathrm{V}_{\mathrm{d}}\right)$ for each size fraction. The dependence of $\mathrm{V}_{\mathrm{d}}$ on surface roughness length, according to particle size and atmospheric stability conditions, has been described previously, ${ }^{11,12}$ and mean values from the earlier work, corresponding to a mixed crops land use category (LUC) and assuming equal periods of stable and unstable conditions, were used here. Recalculation of $\mathrm{V}_{\mathrm{d}}$ to adjust for other LUCs was performed by incorporating the sensitivity to roughness length $\left(\mathrm{z}_{0}\right){ }^{13}$ The selected surface types were typical of southeastern Brazil, and included crops, forest, pasture and water.

\section{Anthropogenic component of aerosol dry deposition}

The magnitude of the increase in aerosol nutrient deposition due to current human activity was determined by considering the difference between the measured atmospheric concentrations, and estimated minimum background concentrations. The latter were based on wet season data reported for Serra do Navio, a remote location in northeastern Brazil. ${ }^{14}$ It is not possible to determine natural background aerosol concentrations in Brazil during the dry season, due to the extensive anthropogenic emissions at this time, especially from biomass burning. Comparisons considered particles smaller than $2.0 \mu \mathrm{m}$ diameter $\left(\mathrm{PM}_{2.0}\right)$ since this was the size fraction measured at Serra do Navio. $\mathrm{PM}_{2.0}$ values for the São Paulo aerosol components were therefore calculated from the chemical component size distribution curves, and used to generate ratios between background and current concentrations. This ratio was then applied to all size fractions.

\section{Meteorological parameters}

Meteorological data were obtained from the São Paulo State University Meteorological Institute (IPMet) station in Bauru (49 $\left.03^{\prime} \mathrm{W}, 22^{\circ} 19^{\prime} \mathrm{S}\right)$. The predominant wind directions recorded between June 2003 and May 2004 were southeasterly and east southeasterly (Figure 2). The highest monthly average temperature was $23.9{ }^{\circ} \mathrm{C}$ in December 2003 (summer), with minima of $18.4^{\circ} \mathrm{C}$ in August 2003 and $17.8{ }^{\circ} \mathrm{C}$ in May 2004 (winter). The lowest monthly mean wind speed $\left(1.7 \mathrm{~m} \mathrm{~s}^{-1}\right)$ was measured in June 2003, and the highest $\left(2.7 \mathrm{~m} \mathrm{~s}^{-1}\right.$ ) in March 2004. Monthly mean relative humidities and precipitation depths reflected the existence of dry and wet seasons. The dry season ran from June through September, with monthly precipitation $<60 \mathrm{~mm}$, and the wet season from November through February, with peak monthly precipitation of $c a .190 \mathrm{~mm}$ in December and January (other months were considered transitional).
5-Day air mass back-trajectories, arriving at 00:00 UTC on each sampling day, $50 \mathrm{~m}$ a.g.l. at the Araraquara site, were calculated using the NOAA HYSPLIT ((HYbrid Single-Particle Lagrangian Integrated Trajectory) model. ${ }^{15}$ The model used the GDAS meteorological dataset, which has a grid resolution of $c a$. 1 degree, and vertical motion calculation employed omega field (the HYSPLIT default).

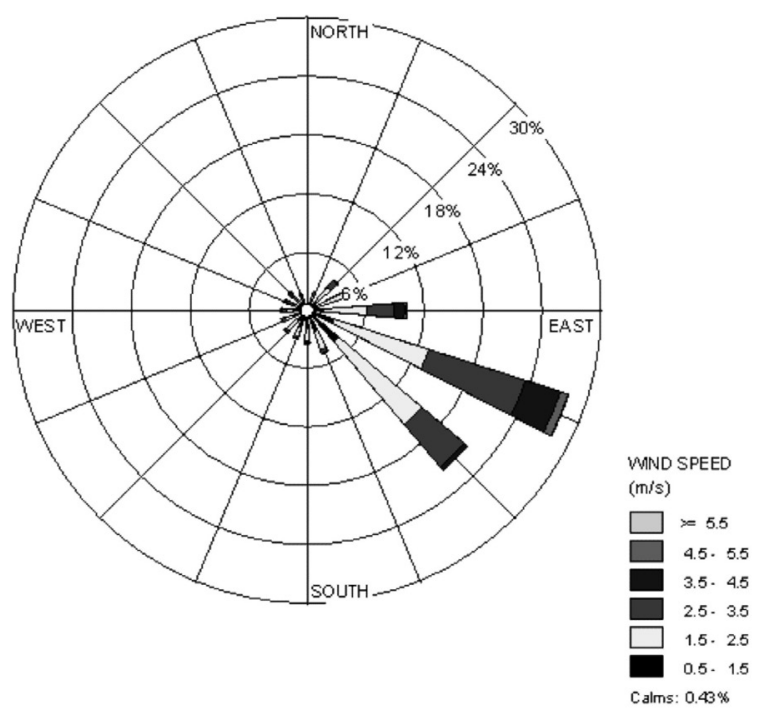

Figure 2. Wind rose showing direction, frequency and strength of winds measured at Bauru between June 2003 and May 2004.

\section{Detection of fires}

Biomass burning is widely used as a management practice during the sugar cane harvest, between May and November. Two sources of biomass burning statistics for São Paulo State were used. The first employed the Moderate Resolution Imaging Spectroradiometers (MODIS) onboard NASA's Aqua and Terra satellites. Fire detection was based on the emission of mid-infrared radiation. ${ }^{16}$ Each fire detection represented the centre of a $1 \mathrm{~km}$ pixel flagged as containing one or more actively burning fires within that pixel. The minimum fire size detectable by these satelliteborne sensors is influenced by many different variables (such as scan angle, biome, sun position, land surface temperature, cloud cover, amount of smoke and wind direction), but is normally $c a .1000 \mathrm{~m}^{2}$.

A separate biomass burning dataset was obtained from the natural resources protection divison (CPRNCoordenadoria de Proteção de Recursos Naturais) of the São Paulo State Environmental Agency (CETESBCompanhia de Tecnologia de Saneamento Ambiental). Prior permission for every sugar cane burning event in São Paulo State is a legal requirement, which results in a record of the time and location of every sugar cane fire. 


\section{Results and Discussion}

\section{Influence of air mass origin on aerosol composition}

Results of trajectory analysis showed that, 5 days prior to arrival at the sampling site, air masses had originated over central and southern regions of the South American continent on $42 \%$, and over the South and Mid-Atlantic Ocean on $22 \%$ of all measurement days. Approximately $25 \%$ of all air masses were classified as mixed, due to roughly equal residence times over the ocean and continent, and $10 \%$ had passed over the São Paulo metropolitan region before arrival. In order to identify any influence of air mass origin on aerosol concentrations, the dataset was divided into subgroups, with allocation to subgroup (i.e. oceanic, continental etc.) being determined by observation of the back trajectory of the air mass arriving at the site on each sample collection day.

For both dry and wet seasons, there were no statistically significant (ANOVA test, $\mathrm{p}>>0.05$ ) differences found between mean particle mass or chemical species concentrations calculated for data grouped according to air mass type, for either $\mathrm{PM}_{2.5}$ or $\mathrm{PM}_{10}$. Particulate mass concentrations were higher during the dry (winter) season, irrespective of air mass origin, with dry / wet season concentration ratios in the range 1.6-3.4 $\left(\mathrm{PM}_{2.5}\right)$, 1.5-2.3 $\left(\mathrm{PM}_{10}\right)$, and 2.6-18.1 (coarse fraction). This can be explained by strong seasonality of biomass burning (reflected in high $\mathrm{K}^{+}$concentrations) and soil dust resuspension (high $\mathrm{Ca}^{2+}$ ). During the dry season, mean concentrations of carbonaceous species and $\mathrm{K}^{+}$(both associated with biomass burning) were similar for all air mass types, and therefore were indicative of an even spatial distribution of biomass burning aerosol sources. Atmospheric aerosol concentrations were therefore governed mainly by regional factors.

\section{Annual biomass burning cycle}

Daily MODIS fire detection frequency for São Paulo State between June 2003 and May 2004 is shown in Figure 3 , together with data from the CPRN database for the municipality of Araraquara and for all of São Paulo State. Fires detected by MODIS increased from ca. 25 per day at the start of the sampling period, reaching a peak of ca. 250 per day in August and September, followed by a progressive decrease until mid-November, after which the daily fire frequency remained at $c a .10-25$ for the remainder of the measurement period.

The daily number of sugar cane fires in São Paulo State, as recorded by CPRN, remained at ca. 20 per day through June and into July, then increased to peak in August and September at ca. 1400 per day, followed by a decline in November and early December. No fires were recorded from late December 2003 through March 2004. Recorded fires then increased during April, reaching peaks of around 800 events per day during May 2004. The daily frequency of sugar cane fires recorded by CPRN for the municipality of Araraquara followed a similar trend as that obtained for São Paulo State. Differences between the two sources (MODIS or CPRN) can be explained by the insensitivity of the satellite-borne sensor to smaller fires, fires occurring

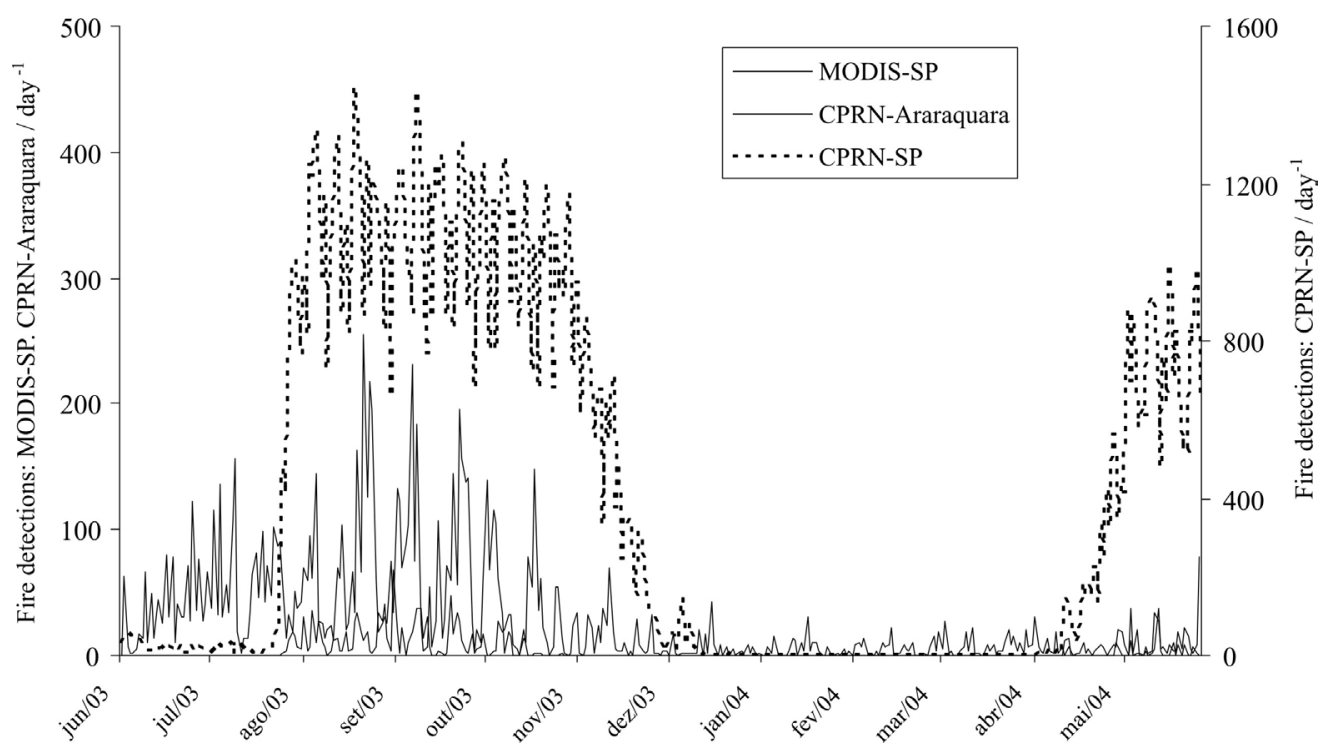

Figure 3. Daily fire frequencies for São Paulo State and Araraquara, obtained from MODIS and CPRN sources. 
between satellite overpasses or under cloud cover, and by its ability to detect all types of fire, including scrub burning and fires on waste ground.

\section{Aerosol source apportionment}

The combined masses of the measured chemical species accounted for $72.5 \%, 51.8 \%$ and $9.4 \%$ of the total masses of $\mathrm{PM}_{2.5}, \mathrm{PM}_{10}$ and $\mathrm{PM}_{>10}$, respectively (Table 1). The unexplained portions of the masses contained material that was not measured, including silicates, carbonates, water and $\left(\mathrm{PM}_{>10}\right.$ only) elemental and organic carbon. PCA analysis identified five components for all size fractions, which explained 90\%, 90\% and 95\% of the total variance for $\mathrm{PM}_{2.5}$, $\mathrm{PM}_{10}$ and $\mathrm{PM}_{>10}$, respectively. Rotated component matrices are presented in Table 2, together with source categories identified from the loadings for the chemical species. For $\mathrm{PM}_{2.5}$ the first principal component (PC1-biomass burning) shows high loadings for $\mathrm{EC}, \mathrm{PO}_{4}^{3-}, \mathrm{K}^{+}, \mathrm{CH}_{3} \mathrm{COO}^{-}$and $\mathrm{HCOO}^{-}$. $\mathrm{PC} 2$ (secondary aerosols) has a major loading for $\mathrm{NH}_{4}^{+}$, and high loadings for $\mathrm{SO}_{4}{ }^{2-}$ and $\mathrm{NO}_{3}^{-}$. $\mathrm{PC} 3$ (resuspended soils and dusts) has major loadings for $\mathrm{Ca}^{2+}$ and $\mathrm{Mg}^{2+}$. PC4 (scavenging of gaseous hydrochloric and nitric acids) has high loadings for $\mathrm{Cl}^{-}$and $\mathrm{NO}_{3}^{-}$. PC5 shows high loadings for $\mathrm{Na}^{+}, \mathrm{Mg}^{2+}$ and $\mathrm{Cl}^{-}$, indicating the presence of marine aerosols. For $\mathrm{PM}_{10}$ and $\mathrm{PM}_{>10}$ size fractions, gas scavenging ( $\mathrm{PC} 4$ for $\mathrm{PM}_{2.5}$ ) did not appear as a separate

Table 1. Mean $\mathrm{PM}_{25}, \mathrm{PM}_{10}$ and $\mathrm{PM}_{>10}$ mass concentrations, and contributions of measured components $(\mathrm{n}=266)$

\begin{tabular}{|c|c|c|c|c|}
\hline & & $\mathrm{PM}_{2.5}$ & $\mathrm{PM}_{10}$ & $\mathrm{PM}_{>10}$ \\
\hline & $\begin{array}{l}\text { Total mass concentration / } \\
\left(\mu \mathrm{g} \mathrm{m}^{-3}\right)\end{array}$ & 26.5 & 41.3 & 44 \\
\hline \multirow{11}{*}{ 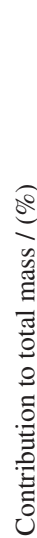 } & $\mathrm{CH}_{3} \mathrm{COO}^{-}$ & 0.21 & 0.17 & 0.15 \\
\hline & $\mathrm{HCOO}^{-}$ & 0.08 & 0.08 & 0.07 \\
\hline & $\mathrm{Cl}^{-}$ & 0.19 & 0.31 & 0.26 \\
\hline & $\mathrm{NO}_{3}^{-}$ & 3.00 & 3.76 & 1.56 \\
\hline & $\mathrm{SO}_{4}^{2-}$ & 9.52 & 6.73 & 2.67 \\
\hline & $\mathrm{PO}_{4}^{3-}$ & 0.35 & 0.34 & 0.37 \\
\hline & $\mathrm{Na}^{+}$ & 0.37 & 0.56 & 0.23 \\
\hline & $\mathrm{NH}_{4}^{+}$ & 2.79 & 1.94 & 0.58 \\
\hline & $\mathrm{K}^{+}$ & 2.58 & 2.07 & 1.35 \\
\hline & $\mathrm{Mg}^{2+}$ & 0.12 & 0.20 & 0.34 \\
\hline & $\mathrm{Ca}^{2+}$ & 0.51 & 0.78 & 1.79 \\
\hline & $\mathrm{EC}$ & 16.23 & 11.86 & $\mathrm{n} / \mathrm{a}$ \\
\hline & $\mathrm{OC}$ & 36.60 & 23.00 & $\mathrm{n} / \mathrm{a}$ \\
\hline & $\begin{array}{l}\text { Sum of contributions of } \\
\text { measured components }\end{array}$ & 72.54 & 51.81 & 9.37 \\
\hline
\end{tabular}

$\mathrm{n} / \mathrm{a}=$ not measured. component, but may have been concealed within the resuspension component. High loadings for $\mathrm{CH}_{3} \mathrm{COO}^{-}$and $\mathrm{HCOO}^{-}$in a separate component indicate the presence of biogenic material.

All five of the source components identified by the PCA procedure were retained for MLRA. Rather than using component score variables, chemical components were selected as source indicators from the component loadings obtained by the PCA process ${ }^{17} \mathrm{EC}$ was used as indicator for biomass burning, substituted by $\mathrm{PO}_{4}^{3-}$ for $\mathrm{PM}_{>10}$ since $\mathrm{EC}$ was not measured in coarse aerosols. For the secondary aerosol source category, the high loadings for $\mathrm{NH}_{4}^{+}$indicated its suitability as a source indicator, in all size fractions. $\mathrm{Ca}^{2+}$ was used as a marker for re-suspended materials. $\mathrm{Cl}^{-}$was selected for the gas scavenging source category $\left(\mathrm{PM}_{2.5}\right.$ fraction only), and $\mathrm{Na}^{+}$for the marine aerosol category. $\mathrm{CH}_{3} \mathrm{COO}^{-}$represented the biogenic category. MLRA with stepwise regression was then performed based on the resultant models describing the aerosol mass:

$$
\begin{aligned}
& \mathrm{PM}_{2.5}=a(\mathrm{EC})+b\left(\mathrm{NH}_{4}^{+}\right)+c\left(\mathrm{Ca}^{2+}\right)+d\left(\mathrm{Cl}^{-}\right)+e\left(\mathrm{Na}^{+}\right)+\mathrm{C} \\
& \mathrm{PM}_{10}=a\left(\mathrm{Ca}^{2+}\right)+b\left(\mathrm{NH}_{4}^{+}\right)+c\left(\mathrm{Na}^{+}\right)+d(\mathrm{EC})+ \\
& e\left(\mathrm{CH}_{3} \mathrm{COO}^{-}\right)+\mathrm{C}
\end{aligned}
$$$$
\mathrm{PM}_{>10}=a\left(\mathrm{NH}_{4}^{+}\right)+b\left(\mathrm{CH}_{3} \mathrm{COO}^{-}\right)+c\left(\mathrm{PO}_{4}^{3-}\right)+d\left(\mathrm{Ca}^{2+}\right)+
$$
$e\left(\mathrm{Na}^{+}\right)+\mathrm{C}$.

Regression coefficients are denoted by $a, b, c, d$ and $e ; \mathrm{C}$ represents the unexplained portion of the mass. Table 3 lists the regression coefficients, standardized beta coefficients $(\beta)$, constants, and the adjusted $r^{2}$ values that indicate the fit of the model. The significance values of the $t$-statistics were below 0.05 for all regression coefficients, except for the gas scavenging component $\left(\mathrm{Cl}^{-}\right)$of the $\mathrm{PM}_{2.5}$ regression model, for which a significance of 0.199 was obtained, and for the marine component $\left(\mathrm{Na}^{+}\right)$of the $\mathrm{PM}_{10}$ regression model, for which a significance of 0.069 was obtained. These components were therefore judged not significant, and were excluded from the model.

For the $\mathrm{PM}_{2.5}$ size fraction, primary biomass burning material contributed $43 \%$, secondary aerosols $31 \%$, and re-suspended material $21 \%$ of the aerosol mass (Table 4). Re-suspension and biomass burning contributed 22\% and $19 \%$, respectively, to the $\mathrm{PM}_{10}$ mass. Re-suspension accounted for approximately half of the mass of $\mathrm{PM}_{>10^{\circ}}$. Masses of $\mathrm{PM}_{2.5}$ and $\mathrm{PM}_{>10}$ were slightly over-estimated, and the model could not account for approximately a third of the total $\mathrm{PM}_{10}$ mass. Overall, these results showed that biomass burning and re-suspension of surface soils, both 
Table 2. Varimax rotated component matrices for (a) $\mathrm{PM}_{2.5}$, (b) $\mathrm{PM}_{10}$ and (c) $\mathrm{PM}_{>10}$ fractions, with proposed aerosol sources

\begin{tabular}{|c|c|c|c|c|c|}
\hline \multirow[b]{2}{*}{ Species } & \multicolumn{5}{|c|}{ Component } \\
\hline & PC1 & $\mathrm{PC} 2$ & PC3 & $\mathrm{PC} 4$ & PC5 \\
\hline (a) $\mathrm{PM}_{2.5}$ & Biomass burning & Secondary aerosols & Re-suspension & Gas scavenging & Marine \\
\hline EC & 0.841 & 0.155 & 0.167 & -0.030 & 0.040 \\
\hline $\mathrm{CH}_{3} \mathrm{COO}^{-}$ & 0.755 & 0.302 & 0.326 & 0.265 & 0.238 \\
\hline $\mathrm{HCOO}^{-}$ & 0.768 & 0.394 & 0.240 & 0.101 & 0.180 \\
\hline $\mathrm{Cl}^{-}$ & 0.116 & 0.138 & 0.135 & 0.913 & 0.254 \\
\hline $\mathrm{NO}_{3}^{-}$ & 0.459 & 0.568 & 0.157 & 0.575 & 0.031 \\
\hline $\mathrm{SO}_{4}^{2-}$ & 0.406 & 0.843 & 0.131 & 0.115 & 0.219 \\
\hline $\mathrm{PO}_{4}^{3-}$ & 0.705 & 0.196 & 0.312 & 0.418 & 0.131 \\
\hline $\mathrm{Na}^{+}$ & 0.210 & 0.191 & 0.229 & 0.269 & 0.883 \\
\hline $\mathrm{NH}_{4}^{+}$ & 0.196 & 0.953 & -0.002 & 0.138 & 0.072 \\
\hline $\mathrm{K}^{+}$ & 0.756 & 0.377 & 0.227 & 0.305 & 0.148 \\
\hline $\mathrm{Mg}^{2+}$ & 0.533 & 0.129 & 0.681 & 0.293 & 0.251 \\
\hline $\mathrm{Ca}^{2+}$ & 0.281 & 0.039 & 0.929 & 0.088 & 0.134 \\
\hline$\%$ variance & 31.4 & 20.6 & 14.8 & 14.3 & 9.2 \\
\hline (b) $\mathrm{PM}_{10}$ & Re-suspension & Secondary aerosols & Marine & Biomass burning & Biogenic \\
\hline $\mathrm{EC}$ & 0.187 & 0.248 & -0.057 & 0.841 & 0.247 \\
\hline $\mathrm{CH}_{3} \mathrm{COO}^{-}$ & 0.337 & 0.267 & 0.193 & 0.268 & 0.802 \\
\hline $\mathrm{HCOO}^{-}$ & 0.405 & 0.342 & 0.167 & 0.293 & 0.735 \\
\hline $\mathrm{Cl}^{-}$ & 0.079 & 0.068 & 0.920 & 0.178 & 0.144 \\
\hline $\mathrm{NO}_{3}^{-}$ & 0.318 & 0.629 & 0.287 & 0.396 & 0.385 \\
\hline $\mathrm{SO}_{4}^{2-}$ & 0.341 & 0.810 & 0.158 & 0.168 & 0.304 \\
\hline $\mathrm{PO}_{4}^{3-}$ & 0.435 & 0.078 & 0.202 & 0.742 & 0.189 \\
\hline $\mathrm{Na}^{+}$ & 0.237 & 0.267 & 0.837 & -0.093 & 0.097 \\
\hline $\mathrm{NH}_{4}^{+}$ & 0.073 & 0.954 & 0.148 & 0.114 & 0.128 \\
\hline $\mathrm{K}^{+}$ & 0.649 & 0.291 & 0.178 & 0.394 & 0.457 \\
\hline $\mathrm{Mg}^{2+}$ & 0.773 & 0.253 & 0.405 & 0.228 & 0.263 \\
\hline $\mathrm{Ca}^{2+}$ & 0.824 & 0.181 & 0.081 & 0.318 & 0.310 \\
\hline$\%$ variance & 20.7 & 20.6 & 16.6 & 16.3 & 16.1 \\
\hline (c) $\mathrm{PM}_{>10}$ & Secondary aerosols & Biogenic & Biomass burning & Re-suspension & Marine \\
\hline $\mathrm{CH}_{3} \mathrm{COO}^{-}$ & 0.377 & 0.739 & 0.313 & 0.336 & 0.240 \\
\hline $\mathrm{HCOO}^{-}$ & 0.412 & 0.744 & 0.261 & 0.269 & 0.299 \\
\hline $\mathrm{Cl}^{-}$ & 0.050 & 0.427 & 0.589 & 0.295 & 0.558 \\
\hline $\mathrm{NO}_{3}^{-}$ & 0.611 & 0.459 & 0.336 & 0.378 & 0.253 \\
\hline $\mathrm{SO}_{4}^{2-}$ & 0.661 & 0.385 & 0.347 & 0.409 & 0.286 \\
\hline $\mathrm{PO}_{4}^{3-}$ & 0.394 & 0.256 & 0.806 & 0.227 & 0.203 \\
\hline $\mathrm{Na}^{+}$ & 0.449 & 0.273 & 0.240 & 0.255 & 0.757 \\
\hline $\mathrm{NH}_{4}^{+}$ & 0.821 & 0.306 & 0.216 & 0.272 & 0.229 \\
\hline $\mathrm{K}^{+}$ & 0.451 & 0.519 & 0.440 & 0.392 & 0.337 \\
\hline $\mathrm{Mg}^{2+}$ & 0.471 & 0.398 & 0.370 & 0.614 & 0.270 \\
\hline $\mathrm{Ca}^{2+}$ & 0.409 & 0.346 & 0.254 & 0.733 & 0.285 \\
\hline$\%$ variance & 25.0 & 22.0 & 17.2 & 16.7 & 14.0 \\
\hline
\end{tabular}


Table 3. Results of multiple linear regression analyses for fine, intermediate and coarse particle size fractions

\begin{tabular}{|c|c|c|c|c|c|c|c|}
\hline \multirow[t]{2}{*}{ Size fraction } & \multicolumn{5}{|c|}{ Regression and Beta coefficients } & \multirow[t]{2}{*}{ Constant } & \multirow[t]{2}{*}{$r^{2}$} \\
\hline & $\mathrm{a}(\beta)$ & $\mathrm{b}(\beta)$ & $c(\beta)$ & $\mathrm{d}(\beta)$ & $\mathrm{e}(\beta)$ & & \\
\hline \multirow[t]{2}{*}{$\mathrm{PM}_{2.5}$} & $\mathrm{EC}$ & $\mathrm{NH}_{4}^{+}$ & $\mathrm{Ca}^{2+}$ & $\mathrm{Cl}^{-}$ & $\mathrm{Na}^{+}$ & -584.45 & 0.79 \\
\hline & $2.83(0.55)$ & $10.18(0.26)$ & $42.06(0.32)$ & - & $19.32(0.07)$ & & \\
\hline \multirow[t]{2}{*}{$\mathrm{PM}_{10}$} & $\mathrm{Ca}^{2+}$ & $\mathrm{NH}_{4}^{+}$ & $\mathrm{Na}^{+}$ & $\mathrm{EC}$ & $\mathrm{CH}_{3} \mathrm{COO}^{-}$ & 11841.32 & 0.67 \\
\hline & $31.23(0.29)$ & $6.22(0.15)$ & - & $1.83(0.37)$ & $82.37(0.21)$ & & \\
\hline \multirow[t]{2}{*}{$\mathrm{PM}_{>10}$} & $\mathrm{NH}_{4}^{+}$ & $\mathrm{CH}_{3} \mathrm{COO}^{-}$ & $\mathrm{PO}_{4}^{3-}$ & $\mathrm{Ca}^{2+}$ & $\mathrm{Na}^{+}$ & -563.57 & 0.89 \\
\hline & $40.76(0.29)$ & $154.53(0.26)$ & $28.07(0.10)$ & $24.96(0.31)$ & $37.50(0.09)$ & & \\
\hline
\end{tabular}

Table 4. Mean modeled component mass concentrations $\left(\mu \mathrm{g} \mathrm{m}^{-3}\right)$ and their percentage contributions to PM mass (in parentheses)

\begin{tabular}{|c|c|c|c|c|c|c|}
\hline Size fraction & Biomass burning & Secondary aerosols & Re-suspension & Marine & Biogenic & Other \\
\hline $\mathrm{PM}_{2.5}$ & $12.0(43)$ & $7.5(31)$ & $5.5(21)$ & $1.9(9)$ & - & $-0.6(-4)$ \\
\hline $\mathrm{PM}_{10}$ & $8.9(19)$ & $5.0(12)$ & $10.0(22)$ & - & $5.8(13)$ & $11.8(35)$ \\
\hline $\mathrm{PM}_{>10}$ & $5.4(10)$ & $12.4(17)$ & $22.5(49)$ & $4.5(8)$ & $12.1(17)$ & $-0.6(-1)$ \\
\hline
\end{tabular}

associated with large-scale agriculture, were the largest sources of aerosols in the study region.

\section{Aerosol dry deposition fluxes}

Dry deposition velocities of atmospheric aerosols are governed by the size of the particles as well as the nature of the surface onto which they are depositing, and are higher for very small particles, which diffuse rapidly to surfaces, and for large particles, which are removed by sedimentation. Both diffusion and sedimentation are inefficient for particles in an intermediate size range (around 0.1-1.0 $\mu \mathrm{m}$ ). Hence, knowledge of the sizedistributed concentrations of aerosol chemical components is an essential prerequisite for deposition flux calculations. The size distributions of potassium, chloride, nitrate, sulphate and phosphate showed submicron and coarse mode peaks (Figure 4). The submicron peaks reflect either emissions during biomass burning (potassium, chloride, phosphate) or secondary production (sulphate). The coarse mode peaks are either indicative of direct emissions of large particles (the only source of coarse mode phosphate), or of scavenging of gases such as $\mathrm{NO}_{\mathrm{x}}, \mathrm{HNO}_{3}, \mathrm{HCl}$ and $\mathrm{SO}_{2}$ onto existing particles. Sodium, magnesium and calcium were mainly present within large particles generated by physical processes. Ammonium and oxalate showed submicron peaks only, due to their formation as secondary aerosols within the atmosphere.

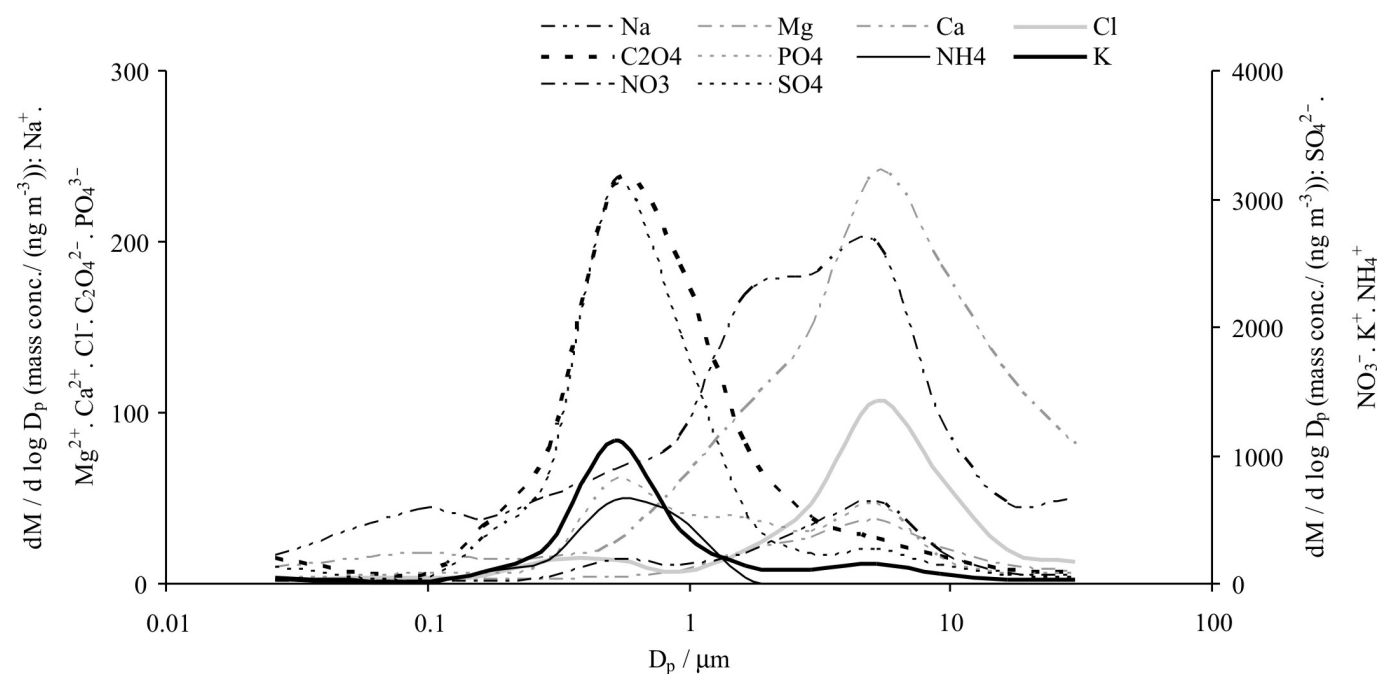

Figure 4. Aerosol size distributions from impactor measurements, using means of all monthly data. 
For most of the measured species, calculated deposition rates were higher during the May to October dry season, than the November to April wet season. Although deposition fluxes of nitrate, potassium and phosphate were higher during the drier winter months (Figure 5), seasonal trends were not identical for all species. The relationship between deposition rate and biomass burning (Table 5) was most evident for potassium $(r=0.76, p<0.01)$, which is directly emitted, and oxalate $(r=0.77, p<0.01)$, which is generated by oxidation of hydrocarbons released during fires, with both species showing higher deposition rates during MayOctober. Nitrate showed a weaker relationship with fire frequency, suggesting the existence of sources additional to biomass burning (such as road transport). Phosphate deposition showed a winter peak in May, and consistently lower fluxes between August and December. Sub-micron and coarse modes in the phosphate size distribution could be explained by biomass combustion and re-suspension of fertilized soils, respectively. In contrast to other species, lack of seasonal trends in ammonium concentrations, and no correlation with fire frequency, can be explained by the existence of different sources of gaseous ammonia, having similar magnitudes during either winter or summer periods. During winter in this region, the main source of ammonia is biomass burning, while emissions from soils and wastes are predominant during summer. ${ }^{18}$ Moderate correlations, with fire frequency, of sulphate $(r=0.55, p<0.1)$, calcium $(\mathrm{r}=0.59, \mathrm{p}<0.05)$ and magnesium $(\mathrm{r}=0.58, \mathrm{p}<0.05)$ can be explained by the emission of $\mathrm{SO}_{2}$ during combustion,
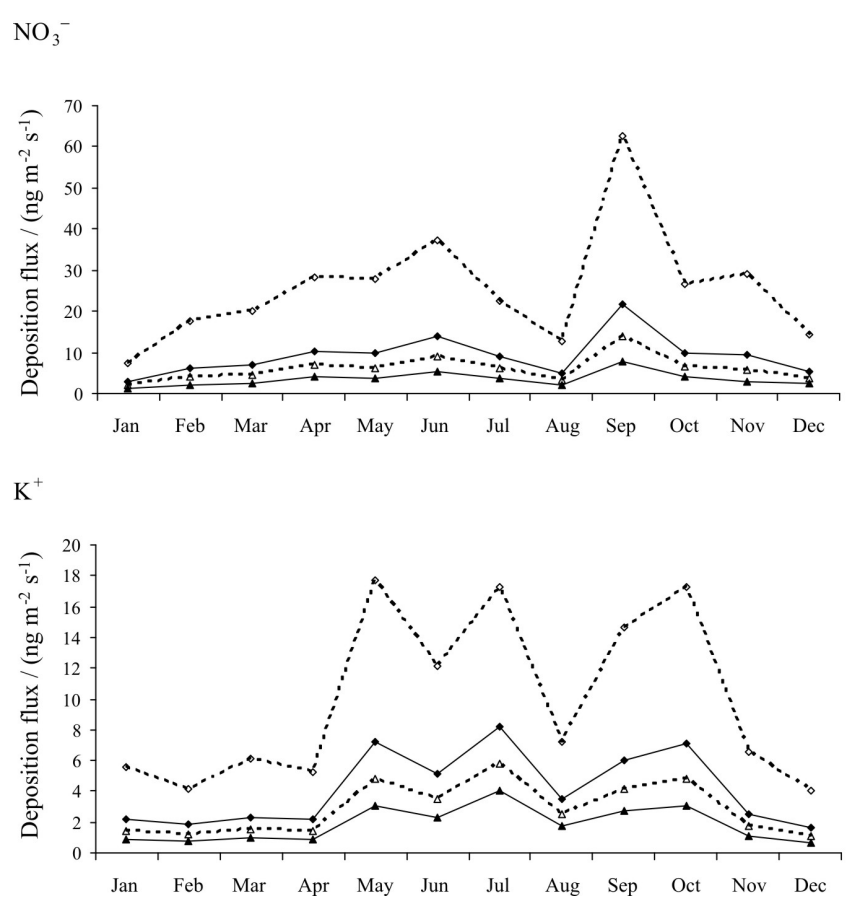

and release of the mineral elements from soils and foliage during fires and vehicle movements in fields.

Deposition fluxes were highest to tropical forest and lowest to water and pasture surfaces, reflecting their different roughness lengths (Table 6). Trends in deposition to the different surfaces were similar, but not identical, for all species, due to their different size distributions. The existence of ammonium within sub-micron aerosols is reflected in a smaller ratio (3.9) between deposition fluxes to tropical forest and water, than obtained for nitrate (ratio of 8.2), a greater fraction of which is present within more rapidly deposited coarse aerosols. The combined dry deposition flux of particulate nitrate- $\mathrm{N}$ and ammonium- $\mathrm{N}$ to sugar cane plantations $\left(0.37 \mathrm{~kg} \mathrm{~N} \mathrm{ha}^{-1} \mathrm{yr}^{-1}\right)$ is equivalent to approximately $0.41 \%$ of fertilizer $\mathrm{N}$ applied annually to plantations (ca. $90 \mathrm{~kg} \mathrm{~N} \mathrm{ha}^{-1} \mathrm{yr}^{-1}$ ). The fluxes of phosphate-P and $\mathrm{K}\left(0.029\right.$ and $\left.0.59 \mathrm{~kg} \mathrm{ha}^{-1} \mathrm{yr}^{-1}\right)$ are equivalent to $0.1 \%$ and $0.49 \%$ of fertilizer applications (ca. $30 \mathrm{~kg} \mathrm{P} \mathrm{ha}^{-1} \mathrm{yr}^{-1}$ and ca. $120 \mathrm{~kg} \mathrm{~K} \mathrm{ha}^{-1} \mathrm{yr}^{-1}$, respectively).

Dry deposition fluxes of all species were much higher than the minimum natural background fluxes (Figure 6), with the exception of sodium and magnesium (due to the nearer proximity of the Serra do Navio site to the Atlantic Ocean, in contrast to the inland São Paulo site, and the prevalence of these ions in marine aerosol). Fluxes to tropical forest were higher than the natural minimum by factors of 12.2 (nitrate), 6.2 (phosphate), 5.0 (chloride), 3.8 (calcium), 2.6 (potassium), 2.5 (ammonium) and 1.8 (sulphate and oxalate). Differences between natural and

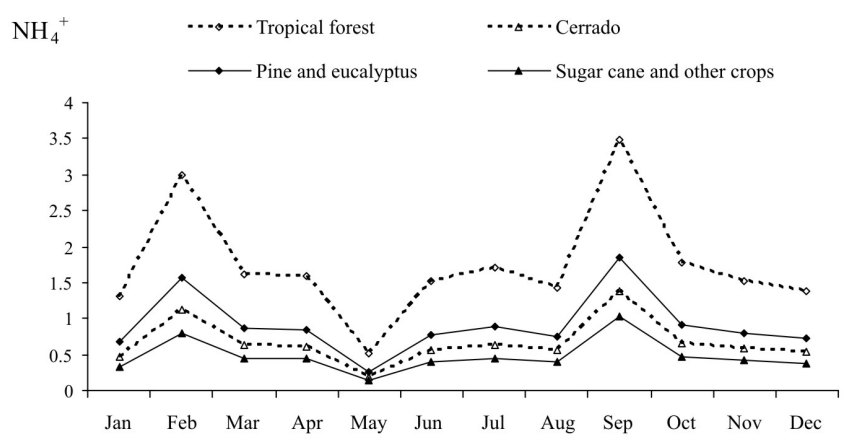

$\mathrm{PO}_{4}{ }^{3-}$

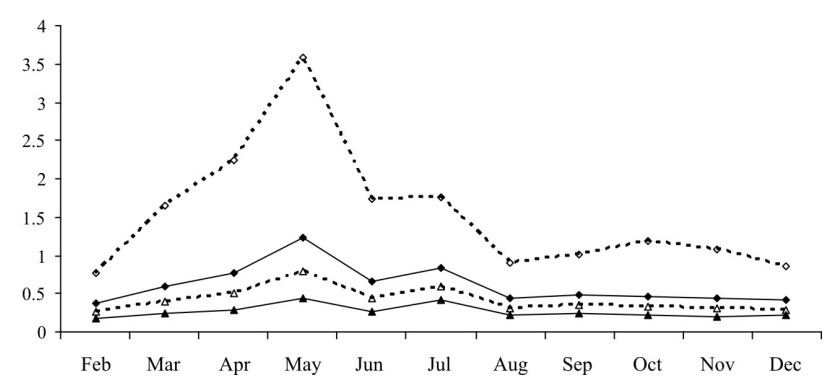

Figure 5. Monthly mean deposition fluxes of nitrate, ammonium, potassium and phosphate, according to surface type. 
Table 5. Average monthly deposition rates to sugar cane $\left(\mathrm{ng} \mathrm{m}^{-2} \mathrm{~s}^{-1}\right)$, number of fires detected (by MODIS) in São Paulo State, and Pearson correlation coefficients $(r)$ obtained between fires detected and deposition rates ( $\mathrm{p}=$ level of significance)

\begin{tabular}{lccccccccccccccc}
\hline & January & February & March & April & May & June & July & August & September & October & November December & $\mathrm{r}$ & $\mathrm{p}$ \\
\hline $\mathrm{Na}^{+}$ & 2.46 & 1.67 & 2.59 & 2.18 & 2.10 & 2.44 & 2.96 & 1.57 & 1.75 & 2.18 & 2.51 & 1.84 & 0.10 & $\mathrm{~ns}$ \\
$\mathrm{NH}_{4}^{+}$ & 0.34 & 0.80 & 0.45 & 0.44 & 0.13 & 0.39 & 0.44 & 0.40 & 1.04 & 0.46 & 0.42 & 0.38 & -0.06 & $\mathrm{~ns}$ \\
$\mathrm{~K}^{+}$ & 0.91 & 0.82 & 0.93 & 0.91 & 3.09 & 2.31 & 4.05 & 1.77 & 2.76 & 3.11 & 1.05 & 0.68 & 0.76 & $<0.01$ \\
$\mathrm{Mg}^{2+}$ & 0.25 & 0.37 & 0.20 & 0.26 & 0.36 & 0.54 & 0.54 & 0.20 & 0.69 & 0.46 & 0.33 & 0.14 & 0.58 & $<0.05$ \\
$\mathrm{Ca}^{2+}$ & 2.64 & 3.47 & 2.04 & 2.73 & 3.98 & 5.37 & 6.94 & 1.79 & 7.37 & 5.03 & 3.26 & 1.62 & 0.59 & $<0.05$ \\
$\mathrm{Cl}^{-}$ & 0.45 & 0.16 & 0.58 & 1.56 & 1.33 & 0.95 & 0.72 & 0.23 & 0.81 & 0.76 & 1.37 & 0.64 & 0.18 & $\mathrm{~ns}$ \\
$\mathrm{NO}_{3}^{-}$ & 1.35 & 2.22 & 2.61 & 4.08 & 3.58 & 5.29 & 3.83 & 1.90 & 7.92 & 4.15 & 3.07 & 2.31 & 0.48 & $\mathrm{~ns}$ \\
$\mathrm{SO}_{4}^{2-}$ & 1.87 & 3.53 & 2.73 & 4.70 & 4.36 & 4.09 & 5.24 & 2.74 & 6.30 & 5.24 & 3.16 & 2.17 & 0.55 & $<0.1$ \\
$\mathrm{C}_{2} \mathrm{O}_{4}^{2-}$ & 0.25 & 0.44 & 0.27 & 0.42 & 0.61 & 0.79 & 1.06 & 0.61 & 0.71 & 0.63 & 0.07 & 0.05 & 0.77 & $<0.01$ \\
$\mathrm{PO}_{4}{ }^{2-}$ & $\mathrm{n} / \mathrm{a}$ & 0.18 & 0.24 & 0.28 & 0.44 & 0.27 & 0.42 & 0.22 & 0.25 & 0.21 & 0.21 & 0.21 & $0.39^{\mathrm{a}}$ & $\mathrm{ns}$ \\
Fires & 3 & 71 & 65 & 199 & 377 & 598 & 566 & 560 & 396 & 409 & 333 & 55 &
\end{tabular}

ns = not significant; ${ }^{\text {a }}$ Excludes January values, due to dust contamination.

Table 6. Annual dry deposition fluxes $\left(\mathrm{kg} \mathrm{ha}^{-1} \mathrm{yr}^{-1}\right)$

\begin{tabular}{lcccccccccc}
\hline & $\mathrm{Na}^{+}$ & $\mathrm{NH}_{4}^{+}$ & $\mathrm{K}^{+}$ & $\mathrm{Mg}^{2+}$ & $\mathrm{Ca}^{2+}$ & $\mathrm{Cl}^{-}$ & $\mathrm{NO}_{3}^{-}$ & $\mathrm{SO}_{4}^{2-}$ & $\mathrm{C}_{2} \mathrm{O}_{4}^{2-}$ & $\mathrm{PO}_{4}^{3-}$ \\
\hline Tropical forest & 3.73 & 0.54 & 3.11 & 0.67 & 6.26 & 1.67 & 8.04 & 6.15 & 0.75 & 0.61 \\
Pine and eucalyptus & 1.53 & 0.28 & 1.31 & 0.27 & 2.66 & 0.63 & 2.89 & 2.65 & 0.33 & 0.23 \\
Savannah & 1.06 & 0.21 & 0.90 & 0.18 & 1.84 & 0.42 & 1.89 & 1.83 & 0.23 & 0.15 \\
Orange and coffee & 0.78 & 0.17 & 0.67 & 0.13 & 1.36 & 0.29 & 1.29 & 1.39 & 0.18 & 0.11 \\
Sugar cane and other crops & 0.69 & 0.15 & 0.59 & 0.11 & 1.21 & 0.25 & 1.11 & 1.21 & 0.16 & 0.09 \\
Pasture & 0.65 & 0.14 & 0.56 & 0.11 & 1.14 & 0.23 & 1.04 & 1.16 & 0.15 & 0.09 \\
Water & 0.62 & 0.14 & 0.54 & 0.10 & 1.08 & 0.22 & 0.98 & 1.10 & 0.14 & 0.08 \\
\hline
\end{tabular}

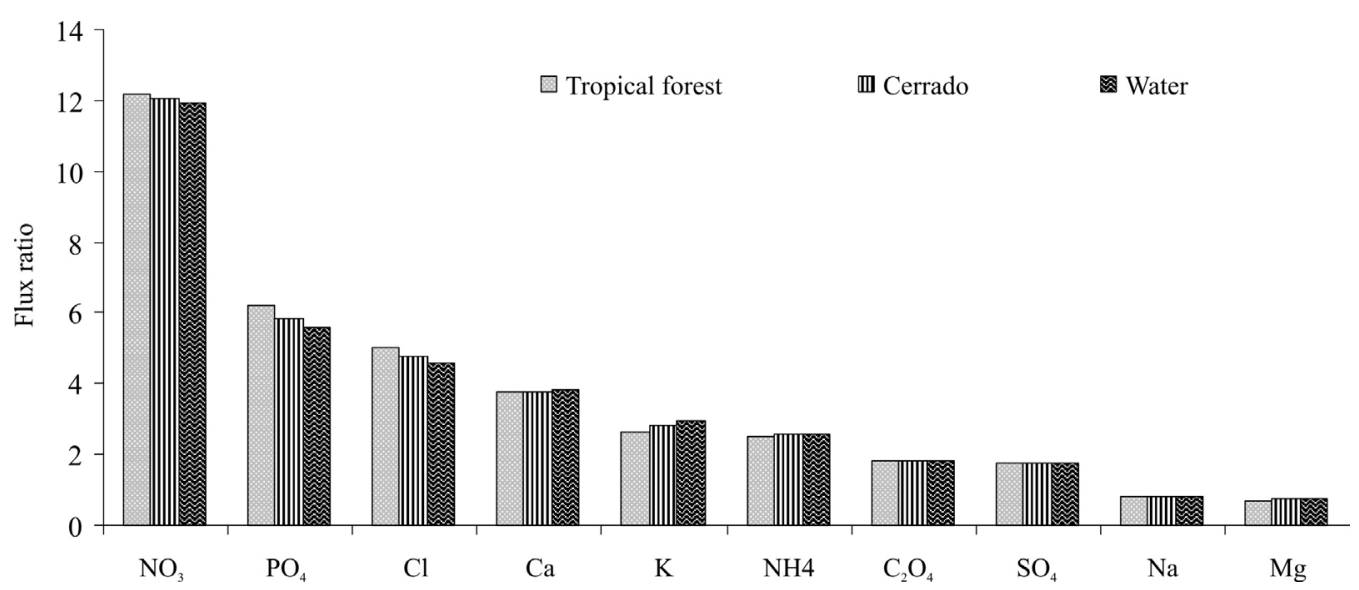

Figure 6. Ratio of aerosol dry deposition fluxes (current / natural background) for three surface types.

perturbed conditions reflect the different atmospheric concentrations of the aerosol species. The values obtained for individual species reflect both differences in atmospheric concentrations and the size range of the particles within which they are found. Hence nitrate, which is mainly present in coarse particles, deposits at a much faster rate than either sulphate or ammonium, both of which are found mainly in slowly depositing fine aerosols.

The particle size distributions of the principal nutrient species (N, P and $\mathrm{K}$ ) were similar for all months of the year (Figure 7). Hence, the contribution to annual deposition of these elements, from greater agricultural activity 

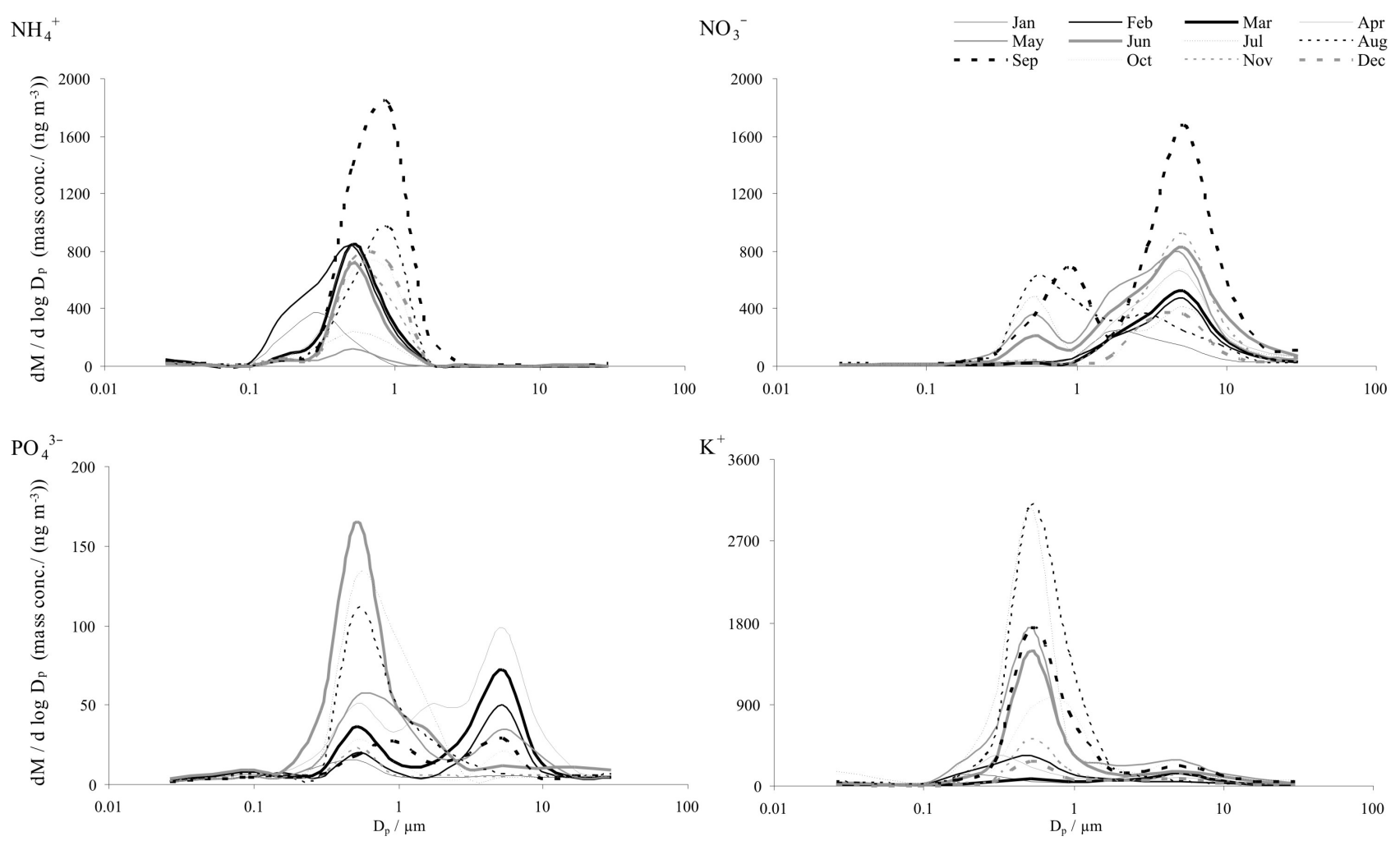

Figure 7. Monthly aerosol size distribution curves for nitrate, ammonium, phosphate and potassium.

during the dry season, can be determined directly from monthly mean deposition rates, without need to correct for changes in size distribution. The mean deposition rates of ammonium, nitrate, phosphate and potassium during the period December through March (no sugar cane burning and diminished general activity) were subtracted from the means for all other months (April through November), during which burning occurred and the overall activity level increased. The resulting deposition rates $\left(\mathrm{ng} \mathrm{m}^{-2} \mathrm{~s}^{-1}\right)$ were converted to an annual equivalent rate $\left(\mathrm{kg} \mathrm{ha}^{-1} \mathrm{yr}^{-1}\right)$, and compared with the total annual deposition fluxes listed in Table 6. Expressed as a percentage of the total annual flux, the incremental deposition (irrespective of surface type) due to dry season activity was $40 \%\left(\mathrm{NO}_{3}{ }^{-}-\mathrm{N}\right), 20 \%$ $\left(\mathrm{PO}_{4}^{3-}-\mathrm{P}\right)$ and $55 \%\left(\mathrm{~K}^{+}\right)$. A small negative value $(-4 \%)$ was obtained for $\mathrm{NH}_{4}^{+}-\mathrm{N}$, which can be explained by the existence of strong sources of $\mathrm{NH}_{3}$ during both wet and dry seasons. This contrasts with $\mathrm{N}, \mathrm{P}$ and $\mathrm{K}$, for which strong emissions during the winter dry season were superimposed on seasonally constant emissions from other sources. Since fertilized soils and biomass burning are strong sources of $\mathrm{NH}_{3}$, it can be concluded that agricultural activity was also the major contributor to deposited $\mathrm{NH}_{4}{ }^{+}-\mathrm{N}$. Agricultural practices were the principal source of potassium, and major sources of $\mathrm{NO}_{3}^{-}-\mathrm{N}$ and phosphorus. Since agricultural activity (including planting and fertilization) continued during the wet season, the above estimates for the dry season represent a conservative estimate of the annual contribution of agriculture to atmospheric nutrient loadings.

\section{Conclusions}

The agriculture industry is the main source of atmospheric aerosols in rural areas of southeast Brazil. Biomass burning and re-suspension are the main contributors to atmospheric particle phase nutrients, and the spatial scale of these sources is regional in extent. No significant differences in aerosol concentrations were detected in air masses originating from different geographical sectors, which suggest that there was only a small contribution of long-range transported material. Although aerosol nutrient dry deposition in this region represents only a small fraction of crop fertilizer requirements in agricultural areas, compared to background conditions there has been a large increase in inputs to natural biomes. Reductions in atmospheric nutrient levels, and therefore inputs to sensitive ecosystems, as well as concomitant improvement of air quality associated with lower particulate loadings, could be achieved by controlling regional emissions. Current and future legislation, introduced by both federal and State governments in Brazil, is expected to increasingly restrict emissions from agricultural biomass burning; however greater mechanization of crop production techniques could increase rates of surface soil dust re-suspension, as well 
as combustion emissions (from machinery and transport vehicles). These changes will further affect aerosol chemical speciation, and hence nutrient deposition fluxes.

\section{Acknowledgments}

Financial support was provided by CNPq, Brazil (Process no. 150547/2007-2), FAPESP, Brazil (Process no. 05/53001-8), and NERC, UK.

\section{References}

1. Vitousek, P. M.; Sanford, R. L.; Annu. Rev. Ecol. Syst. 1986, 17, 137; Avila, A.; Alarcón, M.; Queralt, I.; Atmos. Environ. 1998, 32, 179; Garstang, M.; Ellery, W. N.; McCarthy, T. S.; Scholes, M. C.; Scholes, R. J.; Swap, R. J.; Tyson, P. D.; S. Afr. J. Sci. 1998, 94, 223; Chadwick, O. A.; Derry, L. A.; Vitousek, P. M.; Huebert, B. J.; Hedin, L. O.; Nature 1999, 397, 491; Balestrini, R.; Galli, L.; Tartari, G.; Atmos. Environ. 2000, 34, 1455; Tyson, P. D.; Gatebe, C. K.; S. Afr. J. Sci. 2001, 97, 106.

2. Bobbink, R.; Heil, G. W.; Raessen, M. B.; J. Ecol. 1998, 86, 717. Henry, R.; Ecologia de Reservatórios: Estrutura, Função e Aspectos Sociais; UNESP: Botucatu, Brazil, 1999; Chen, L.; Driscoll, C. T.; Atmos. Environ. 2004, 38, 4099; Galloway, J. N.; Townsend, A. R.; Erisman, J. W.; Bekunda, M.; Cai, Z.; Freney, J. R.; Martinelli, L. A.; Seitzinger, S. P.; Sutton, M. A.; Science 2008, 320, 889; Davis, S. M. In Everglades: The Ecosystem and Its Restoration; Davis, S. M.; Ogden, J. C., eds.; St. Lucie Press: Florida, 1994; Ahn, H.; James, R. T.; Water, Air, Soil Pollut. 2000, 121, 43; Aidar, M. P. M.; Schmidt, S.; Moss, G.; Stewart, G. R.; Joly, C. A.; Plant Cell Environ. 2003, 26, 389; Oliveira, M. A.; Grillo, A. S.; Tabarelli, M.; Oryx 2004, 38, 389.

3. Reay, D. S.; Nature 2004, 427, 485.

4. Cleveland, C. C.; Townsend, A. R.; Proc. Natl. Acad. Sci. USA 2006, 103, 10316.

5. Fu, J. M.; Winchester, J. W.; Geochim. Cosmochim. Ac. 1994, 58, 1581; Vitousek, P. M.; Aber, J. D.; Howarth, R. W.; Likens, G. E.; Matson, P. A.; Schindler, D. W.; Schlesinger, W. H.; Tilman, D. G.; Ecol. Appl. 1997, 7, 737; Downing, J. A.; McClain, M.; Twilley, R.; Melack, J. M.; Elser, J.; Rabalais, N. N.; Lewis, W. M. Jr.; Turner, R. E.; Corredor, J.; Soto, D.; Yanez-
Arancibia, A.; Kopaska, J. A.; Howarth, R. W.; Biogeochemistry 1999, 46, 109; Holland, E. A.; Dentener, F. J.; Braswell, B. H.; Sulzman, J. M.; Biogeochemistry 1999, 46, 7.

6. http://www.fao.org/es/ess/, accessed in September 2008.

7. http://www.ibge.gov.br/home/estatistica/indicadores/ agropecuaria, accessed in June 2008; Rudorff, B. F. T.; Berka, L. M. S.; Moreira, M. A.; Duarte, V.; Rosa, V. G. C.; Report No. 11421-RPQ/762, Instituto Nacional de Pesquisas Espaciais, São José dos Campos, Brazil, 2004.

8. Da Rocha, G. O.; Franco, A.; Allen, A. G.; Cardoso, A. A.; J. Geophys. Res. 2003, 108(D7), 4207.

9. Yin, J.; Allen, A. G.; Harrison, R. M.; Jennings, S. G.; Wright, E.; Fitzpatrick, M.; Healy, T.; Barry, E.; Ceburnis, D.; McCusker, D.; Atmos. Res. 2005, 78, 149.

10. Horvath, H.; Atmos. Environ. 1993, 27, 292; Horvath, H.; J. Aerosol Sci. 1997, 28, 1149.

11. Nho-Kim, E. Y.; Michou, M.; Peuch, V. H.; Atmos. Environ. 2004, 38, 1933.

12. Zhang, L.; Gong, S.; Padro, J.; Barrie, L.; Atmos. Environ. 2001, $35,549$.

13. Zhang, L.; Brook, J. R.; Vet, R.; Atmos. Chem. Phys. 2003, 3, 2067.

14. Gerab, F.; Artaxo, P.; Gillett, R.; Ayers, G.; Nucl. Instrum. Methods Phys. Res., Sect. B 1998, 136, 955.

15. Draxler, R. R.; Rolph, G. D.; HYSPLIT (HYbrid SingleParticle Lagrangian Integrated Trajectory) Model, access via http://www.arl.noaa.gov/ready/hysplit4.html, NOAA Air Resources Laboratory, Silver Spring: MD, 2003.

16. Giglio, L.; Descloitres, J.; Justice, C. O.; Kaufman, Y. J.; Remote Sens. Environ. 2003, 87, 273.

17. Jennings, S. G.; Ceburnis, D.; Allen, A. G.; Yin, J.; Harrison, R. M.; Wright, E.; Fitzpatrick, M.; Wenger, J.; Moriarty, J.; Sodeau, J.R.; Barry, E.; Irish Environmental Protection Agency report, Project 2000-LS-6.1.M1, Dublin, Ireland, 2005.

18. Machado, C. M. D.; Cardoso, A. A.; Allen, A. G.; Environ. Sci. Technol. 2008, 42, 381.

Received: March 19, 2009

Web Release Date: October 16, 2009

FAPESP helped in meeting the publication costs of this article. 